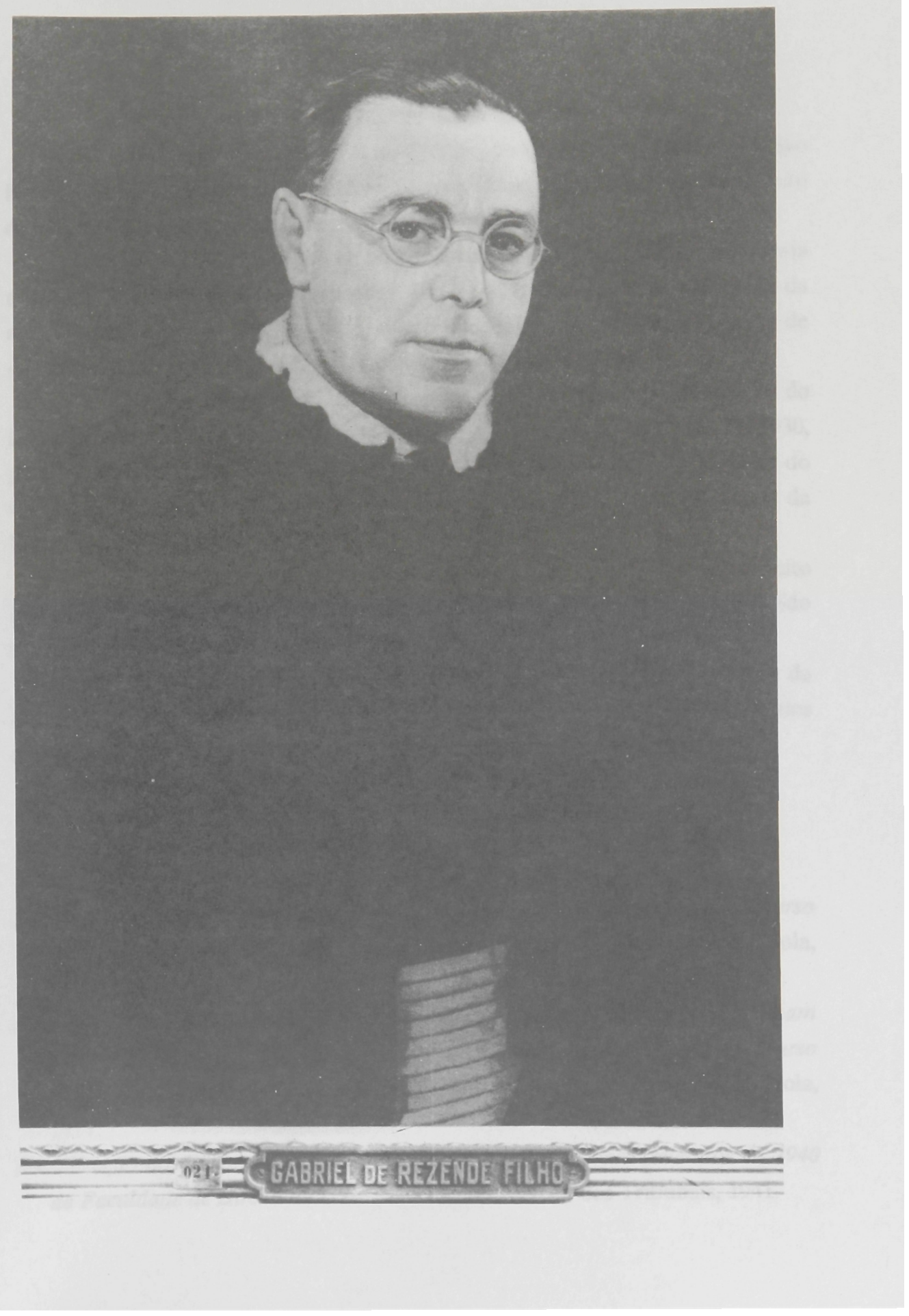





\section{GABRIEL JOSÉ RODRIGUES DE REZENDE FILHO}

(1945-1948)

Nasceu em São Paulo a 23 de junho de 1893.

Fez o curso secundário no Colégio do Carmo e no Ginásio de São Bento. Em 1909, quando contava 15 anos, matriculou-se na Faculdade de Direito de São Paulo, obtendo o grau de bacharel em 1913.

Em 1917, inscreveu-se no concurso para lente substituto de Teoria e Prática do Processo Civil e Comercial. Em 1919, foi nomeado livre-docente da mesma cadeira, sendo que, em 1921, com o falecimento do professor Estevão de Almeida, passou a reger a cadeira, tendo-se doutorado em 1925.

Foi secretário do Dr. Washington Luis, quando presidente do Estado, de 1920 a 1924, diretor do Tribunal de Contas, de 1925 a 1930, procurador do curador fiscal do Estado, de 1930 a 1937, além de membro do Conselho Nacional de Ensino, como representante dos livres-docentes da Faculdade de Direito de São Paulo.

Em janeiro de 1934, tornou-se professor catedrático de Direito Judiciário Civil e, em 1945, foi nomeado diretor da Faculdade de Direito de São Paulo, permanecendo até 1948.

Foi membro da Ordem dos Advogados do Brasil, do Instituto da Ordem dos Advogados e da União Brasil-Estados Unidos. Publicou vários artigos na Revista da Faculdade de Direito e na Revista dos Tribunais.

Faleceu nesta capital a 20 de novembro de 1957.

\section{Obras Publicadas}

Por que principios se rege a apellação de terceiros?: dissertação de concurso apresentada à Faculdade de Direito de São Paulo. São Paulo : Espindola, 1917.

Para que se dê a competência do fôro do contrato é essencial que as partes tenham feito renuncia expressa do fôro do domicilio: dissertação de concurso apresentada à Faculdade de Direito de São Paulo. São Paulo : Espindola, 1917.

Socialização do direito: oração do paraninfo à turma dos bacharelandos de 1940 da Faculdade de Direito da USP. São Paulo : Revista dos Tribunais, 1941. 
Curso de direito processual civil. São Paulo: Saraiva, 1948. 3 vs.

Ações que não admitem a reconvenção. Revista da Faculdade de Direito de São Paulo, São Paulo, v. 53, p. 59-73, 1958. 